\title{
屋根瓦に作用する風力の測定 \\ Wind Force on Roof Tiles
}

岡田 創*

Hajime OKADA

\section{1.はじめに}

瓦屋根は住宅などの低層建築物において最も代表的に 用いられる屋根莫き工法の 1 つであるが，従来から台風 の襲来などによる強風被害の発生の都度, 飛散などの被 害が度々報告されている. 図 1 に示寸ように瓦屋根は瓦 と下地材との間に隙間（以下，内部空間と呼ぶ）を有し ており，この内部空間は個々の瓦の隙間を通じて外部と 通じている. このため, 瓦の内圧の評価は困難なものと なっており，瓦に作用する風力の評価が適切になされて いなかったことが依然として強風時の被害が報告される 要因の 1 つとしてあげられる.

瓦の飛散に関する研究としては, 縮尺 $1 / 20$ で精密に再 現された瓦模型を模型屋根に莫いて行った岡田 ${ }^{1)} の$ 実験 がある. 岡田は, 風速を段階的に変えて瓦の挙動を観察 し, 一部の瓦に動摇が生じてから飛散に至り, その後こ れに連鎖して瓦の飛散する領域が周辺に拡大寸る様子を 明らかにしている. このとき，瓦に作用する風圧あるい は風力は直接測定されておらず, 飛散時の風力の推定は 飛散の生じた風速より間接的に行っている.

瓦に作用する風圧力を実大の瓦を用いて風洞実験によ り測定した研究としては, 熟尾ら ${ }^{2)}$, 立川 ${ }^{3)}$, 森崎ら ${ }^{4}$ のものがある. これらの研究では, 実大の瓦を用いた屋 根の一部分を風洞の吹き出し口に設置し, 瓦の表面及び 裏面の平均風圧の測定を行っている. ただし, いずれも

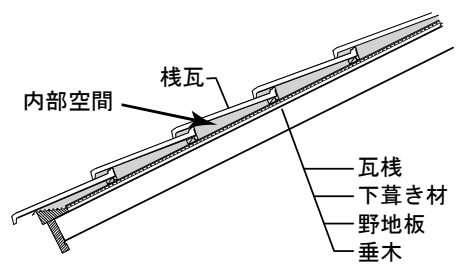

図 1 瓦屋根の構造

瓦に作用する平均風圧の性状に着目しており, 内圧や風 力の変動性状については明らかにされていない.また, いずれの研究も実験気流として一様流を用いており, 自 然風の有する気流の乱れが瓦の風圧力に及ぼす影響は言 及されていない．

瓦の内圧に関する研究についてみると, C. Kramer et al. ${ }^{5)}$ は，瓦の隙間の空隙率を実験的に評価して瓦の内部 空間に出入りする気流の流量を一定とした仮定の下に, 瓦の隙間の通風量の測定結果より有効面積を評価して平 均内圧係数を推定している. また R.A. Hazelwood ${ }^{0}$ は瓦屋 根に作用する外圧の分布に釣り合うような内部空間内の 流れを仮定して瓦に作用寸る風力を評価している. しか し，これらの検討は外圧と内圧の定常的な釣り合いに関 するものであり, 内圧の変動性状を明らかにするもので はない. なお， R.A. Hazelwood ${ }^{7}$ は風洞内で風路を塞いだ カーテンを急激に解放することにより瓦屋根に急激な圧 力変動を作用させ，内圧は極めて短時間で外圧と等しく

* (株) 泉創建エンジニアリング 主任研究員

Chief Research Engineer, Izumisohken Engineering Co., Ltd. 
なることを示した．このことは，瓦の内圧は外圧変動に 対して準静的に応答寸るとして扱う可能性を示唆するも のであるが，屋根面に外圧変動が作用したときの瓦の内 圧変動の評価については明らかにしていない.

以上に述べたように，風洞実験により測定された瓦の 風圧力は実瓦を用いて測定されたものがほとんどである. これは，縮尺模型を用いた実験により瓦の内圧を直接測 定することは瓦間の隙間の模型化など困難な点が多いこ とによるものである. しかし，これらの実験は乱れの少 ない気流で行われており, 自然風の有する気流の乱れが 瓦に作用寸る風圧力, 特に瓦の飛散に繋がるような負側 ピーク風力に及ぼす影響は明らかになっていなかった。

その後, 筆者等が実施した切妻屋根に設置した実大の 瓦を用いた実測 ${ }^{8)}$.9 や河井等が実施した寄棟屋根に実大

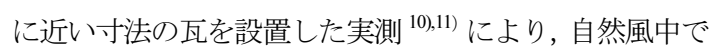
瓦に作用寸る風圧力の性状が明らかなものとなってきた. 本項では筆者等が実施した実大建物を用いた屋根瓦の風 圧力の測定結果について紹介寸る.

\section{2. ピーク風力の性状}

図 2 に計測対象の建物の外観を示寸. 計測対象は切妻 屋根の 2 階建て建物である. 建物の平面形状は $5.4 \mathrm{~m} \times$ $4.8 \mathrm{~m}$ の長方形平面で棟高さは $6.7 \mathrm{~m}$ である. 切妻屋根の 片面にF形瓦，もう 1 面に J 形瓦を設置し，図 3 に示寸 位置に風圧測定瓦を設置した. 屋根瓦に作用する風圧力 の測定は，瓦に浮上りがない状態と瓦の先端に人工的な 浮上りを設けた状態について行った. 人工的な浮上りは, 瓦が飛散する直前に瓦がばたついたり浮き上がったりし ている状態を模擬して作用する風力を測定することを目 的として設けたものである. 瓦の形状の違いによる差異 は屋根の部位による差と比較して小さいことから, 以下 ではF 形瓦の測定結果について示す.

図 4 に浮上りがない瓦に作用する正側ピーク風力係数 $\hat{C}_{F, \text { max }}$, 負側ピーク風力係数 $\hat{C}_{F, \text { min }}$ 及び平均風力係数 $\bar{C}_{F}$ の風向 $\theta$ による変化の例として, 妻側端部の F2 瓦と 屋根中央の一般の F8 瓦の測定結果を示す.

いずれの瓦もピーク風力係数と比較して平均風力係数 の值は小さく, F2 瓦の $\theta=75^{\circ}$ 付近で- 1 程度の值を示す 他はほぼゼロと見な寸ことができる. 妻側端部の F2 瓦 の負側ピーク風力係数 $\hat{C}_{F, \text { min }}$ の值は, 正側ピーク風力係 数 $\hat{C}_{F, \text { max }}$ と比較して大き $<\theta=60 \sim 90^{\circ}$ で $-3 \sim-5$ の值を 示寸. 屋根中央の F8 瓦では, $\hat{C}_{F, \min }$ の值の風向による 変化は $\mathrm{F} 2$ 瓦と比較して小さく, 各風向で $\hat{C}_{F, \max }$ と同程 度の值を示す. F8 瓦では, $\hat{C}_{F, \text { min }}$ の值は妻面に正対する

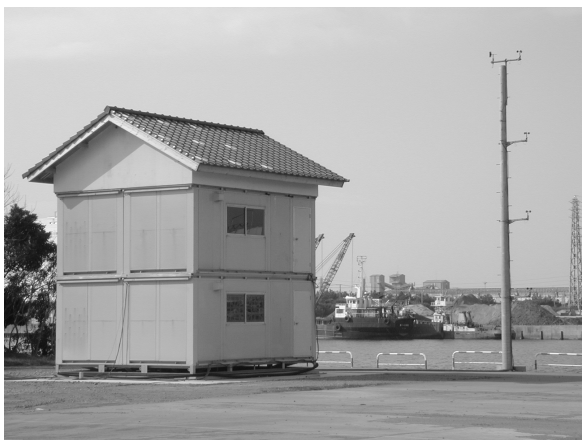

図 2 計測対象建物 ${ }^{12)}$

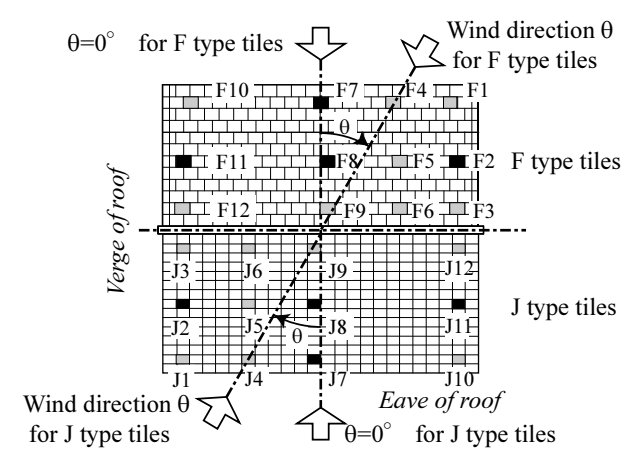

図 3 風圧測定瓦の設置位置と風向の関係 ${ }^{12)}$

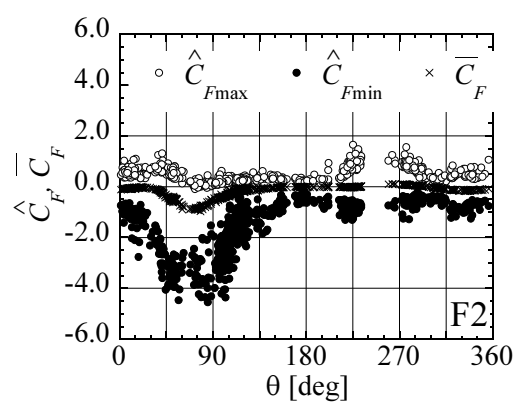

(a) F2 瓦

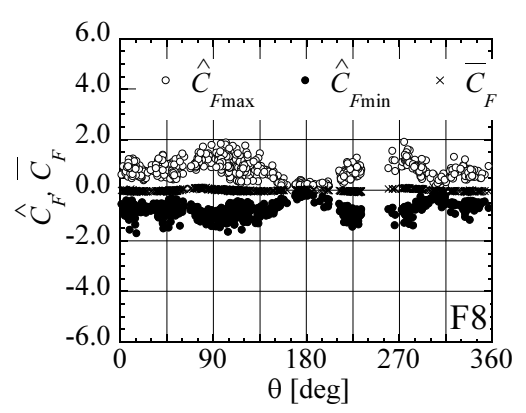

(b) F8 瓦

図 4 正側ピーク風力係数 $\hat{C}_{F, \text { max }}$, 負側ピーク風力係数 $\hat{C}_{F, \text { min }}$ 及び平均風力係数 $\bar{C}_{F}$ の風向 $\theta$ による変化 ${ }^{12)}$ (浮上りが無い場合) 


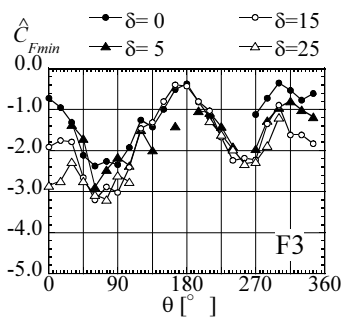

(a)F3 瓦

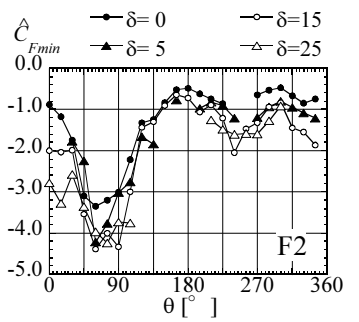

(e)F2 瓦

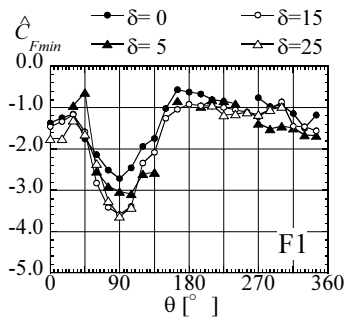

(i)F1 瓦

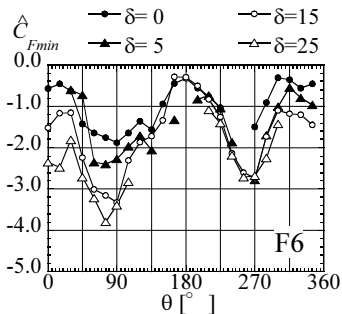

(b)F6 瓦

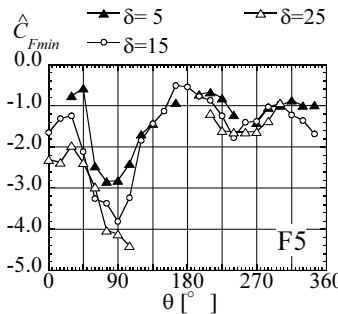

(f)F5 瓦

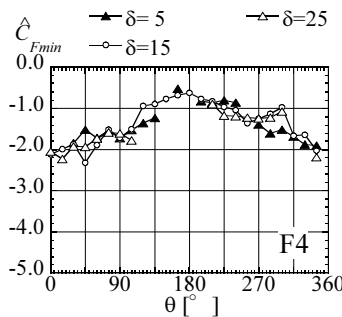

(j)F4 瓦

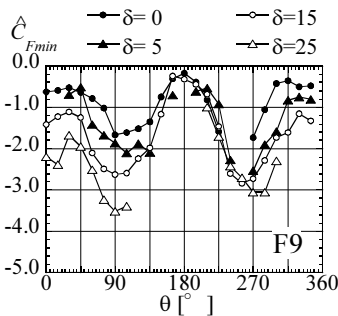

(c)F9 瓦

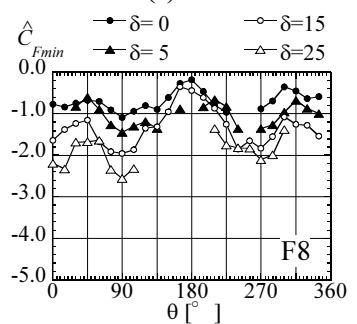

(g)F8 瓦

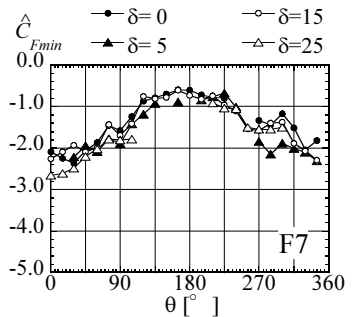

(k)F7 瓦

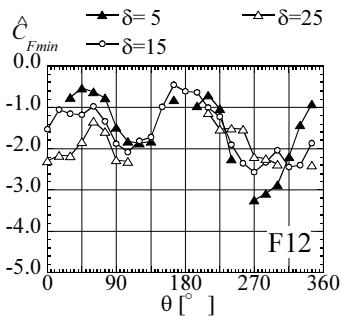

(d)F12 瓦

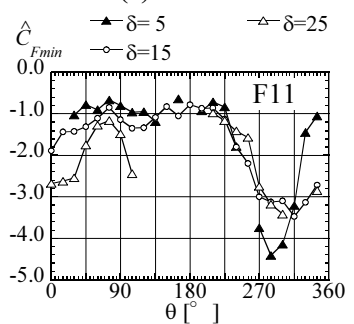

(h)F11 瓦

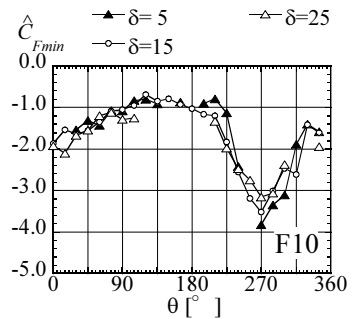

(l)F10 瓦

図 5 浮上り量 $\delta$ を $0,5 \mathrm{~mm}, 15 \mathrm{~mm}, 25 \mathrm{~mm}$ とした時の負側ピーク風力係数 $\hat{C}_{F, \min }$ と風向 $\theta$ の関係 ${ }^{12)}$

風向 $\theta=90^{\circ}$ と $270^{\circ}$ 付近で極小を示しその値はー1〜一 2 程度である。

図 5 に浮上り量 $\delta$ を $0,5 \mathrm{~mm}, 15 \mathrm{~mm}, 25 \mathrm{~mm}$ とした時 の負側ピーク風力係数 $\hat{C}_{F, \min }$ と風向 $\theta$ の関係の浮上り量 の関係を示す。ここで, 図中のプロットは風向 $15^{\circ}$ 毎の 測定結果のアンサンブル值である. また, F4,F5,F10～F12 瓦は $\delta=0$ については測定を行っていない.

屋根中央の軒先側に位置する F4 瓦と F7 瓦を除き，い ずれの瓦についても浮上り量 $\delta$ の増加に伴って負側ピー ク風力係数の值が極小值を示寸風向で大きくなる. また, $\mathrm{J}$ 形瓦には見られないが $\mathrm{F}$ 形瓦では，屋根の中段より上 側の瓦では風向 $\theta=0^{\circ}$ 付近でも浮上り量 $\delta$ の増加に伴 って負側ピーク風力係数の值が大きくなる.

文献 9 では負側ピーク風力が生じる時の外圧係数と内 圧係数の瞬間值について検討している.浮上りに伴って, 屋根から剥離した気流の場にある F2 瓦などの妻面側に ある瓦では外圧係数の瞬間值は $\delta$ が生じることにより負 側に変化する. また, F8 瓦のように気流の再付着点より 風下側にある瓦では再付着した気流の一部が吹き込むこ とにより内圧係数の瞬間值が正側に変化し, 負側ピーク
風力係数が大きくなっている. 屋根中央の軒先側に位置 する瓦では浮上りによる負側ピーク風力係数の変化が小 さいが，これらの瓦では浮上りに伴って外圧係数と内圧 係数のいずれも同程度変化し，その結果負側ピーク風力 係数の值の変化は小さくなっている.

\section{3. 屋根面風圧測定結果に基づく内圧の推定}

以上では，実大建物を用いた自然風中における瓦に作 用する風力の性状について述べた. しかし, 多様な形状 の屋根における瓦に作用する風力を評価するためには， 縮尺模型を用いた風洞実験に基づき風力を推定する手法 が必要となる. 変動内圧に関する研究としては室内圧を 対象とした研究が多数行われており ${ }^{13)}$, 瓦の内圧の推定 する上でこれらが参考になる．瓦における外圧の主な伝 播経路は多数の瓦と瓦の間の隙間である.これらは複雑 な形状をしており，隙間における圧力損失の評価が内圧 を推定する上で課題となる．また，隙間の面積は瓦 1 枚 あたりの内部空間の容積と比較すれば比較的大きく，必 ずしも Helmholtz 共鳴を無視しうるとはいえない. 筆者 等は，実瓦を用いた風洞実験より瓦の隙間における圧力 
損失などのパラメーターを定め，同時測定された屋根面 風圧の測定結果に基づき瓦の内圧を推定する手法につい て検討している ${ }^{14)}$. 屋根面全体を対象とした場合, 内部 空間を区画する栈木などの影響は小さく, 内圧変動は屋 根面全体でほぼ一様であり, パワースペクトル密度には Helmholtz 共鳴に対応するピークは見られない.このため, 同時測定された屋根面風圧を空間平均した值と個々の瓦 の隙間を評価して推定した内圧変動はほぼ一致する. 図 6 に浮上りが無い場合の風力係数について, 内圧を同時 測定した外圧の空間平均値として推定した值と実測結果 の比較を示すが, 両者は良い一致を示寸. ただし, 浮上 りが生じた場合, 浮上りによる局部的な外圧及び内圧の 変化の評価が課題として残る ${ }^{9}$.

\section{4.まとめ}

本項では実測より得られた屋根瓦に作用寸る風力の性 状及び風洞実験で得られた屋根面風圧の測定結果から瓦 の内圧を推定する手法について述べた. 2001 年に瓦屋根 標準設計・施工ガイドライン ${ }^{15)}$ が制定され，ガイドライ ンに基づき施工された瓦屋根の而風性能が向上している ことが期待される. しかし，瓦に浮上りが生じることを 考慮すると浮上りによる負側ピーク風力の変化を評価す る必要がある、筆者等は, 実測結果に基づき浮上りに伴 う負側ピーク風力と浮上り量の関係を線形に仮定し, 瓦 屋根の耐風性能を評価寸る手法を提案している ${ }^{16}$.

\section{参考文献}

1) 岡田 恒, 強風による屋根瓦の飛散に関する風洞実験, 日本風工学会誌，第 35 号，pp.1-15，1988.4

2) 熟尾健三, 鳥海 勲, 台風による瓦屋根の飛散防止に 関寸る研究, 建築学会研究報告, 第 12 号, pp.37-39, 1951 3) 立川正夫, 屋根瓦の飛散について, 日本建築学会大会 梗概集，pp.921-922， 1971

4) 森崎禔璋, 斉藤通, 本田明弘, 佐藤勝彦, 屋根瓦に作 用する風力に関する研究, 日本風工学会誌, 第 58 号, pp.19-31, 1994.1

5) C. Kramer and H. Gerhaldt, Wind loads on permeable roofing systems, Journal of wind engineering and industrial aerodynamics, Vol. 13, pp.347-358, 1983

6) R.A. Hazelwood, The interaction of the two principal wind forces on rood tiles, Journal of wind engineering and industrial aerodynamics, Vol.8, pp.39-48, 1981

7) R.A. Hazelwood, Principles of wind loading on tiled roofs and their application in the British Standard BS5534, Journal of

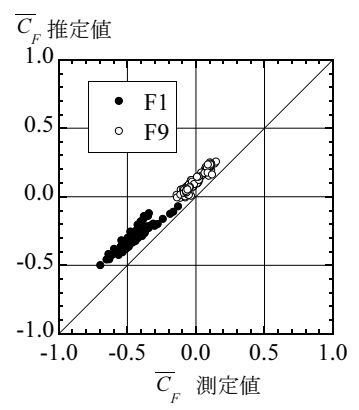

(a) $\bar{C}_{F}$

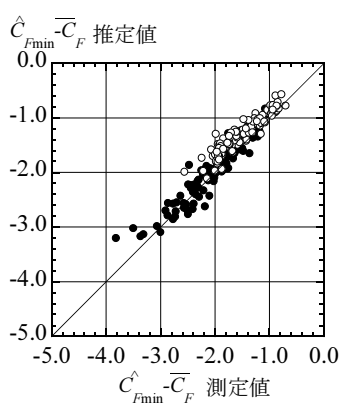

(b) $\hat{C}_{F, \min }-\bar{C}_{F}$
図 6 浮上りがない瓦の風力係数推定值 と実測結果の比較 ${ }^{8)}$

wind engineering and industrial aerodynamics, Vol.6, pp.113-124, 1980

8) 岡田創, 大熊武司, 片桐純治, 浮上りが生じていない 瓦に作用する風圧力の性状 実大建物による屋根瓦に作 用する風力に関寸る研究 その 1 , 日本建築学会構造系 論文集，第 588 号，pp.49-56，2002.2

9) 岡田創, 大熊武司, 片桐純治, 浮上りが生じた瓦に作 用寸る風圧力の性状 実大建物による屋根瓦に作用寸る 風力に関寸る研究 その 2 , 日本建築学会構造系論文集, 第 622 号, pp.57-64, 2007.12

10) 河井宏允, 西村宏昭, 自然風中における屋根瓦に作 用寸る風力の特性について, 第 17 回風工学シンポジウム, pp.327-332， 2002

11）西村宏昭, 河井宏允, 屋根瓦の而風設計用風力係数, 第 18 回風工学シンポジウム, pp.473-478, 2004

12) 岡田創, 瓦屋根の而風性能評価方法に関する研究, 神奈川大学学位論文, 2009.3

13)例えば, J.D. Holmes, Mean and fluctuating internal pressures induced by wind, Proc. of the 5th International conference on Wind Eng., Fort Collins, Colorado, Vol.1, pp.IV-8-1 - IV-8-16, 1979

14) 岡田創, 大熊武司, 片桐純治, 屋根瓦の裏面に作用 寸る風圧予測に関寸る研究, 日本建築学会構造系論文集, 第 633 号, pp.1943-1950，2008.11

15)瓦屋根標準設計・施工ガイドライン : 社団法人全日本 瓦工事業連盟, 全国陶器瓦工業組合連合会, 全国厚形久 レート組合連合会, 2001

16) H. Okada, J. Katagiri and T. Ohkuma, Study on method for evaluating wind performance of tiled roof, APCWE 7, Taipei, 2009 